DARIUSZ MILEWSKI* - WARSZAWA

\title{
MOLDAWIA W RELACJACH NUNCJUSZÓW APOSTOLSKICH W POLSCE W LATACH 1648-1653
}

Stosunki Rzeczypospolitej z Portą Ottomańską oraz jej naddunajskim lennikami, w tym szczególnie z przychylną Polsce Mołdawią, stały się przedmiotem zainteresowania dyplomacji papieskiej, zwłaszcza od czasów znanych szeroko w Europie planów wojny tureckiej Władysława IV. Nic dziwnego zatem, iż doniesienia o wydarzeniach w samej Mołdawii - z którą, przypomnijmy, wiązano od 1646 r. tak duże nadzieje na jej czynny udział w wystąpieniu przeciw Turcji i które tak boleśnie zawiódł hospodar Bazyli Lupul, organizując słynne „pokojowe" poselstwo Dziebałtowskiego do Stambułu jesienią 1646 r. i wymawiając się ostatecznie od jawnego poparcia planów wojennych króla polskiego - a także płynące stamtąd wiadomości o poczynaniach Turków i Tatarów, zajęly poczesne miejsce w raportach kolejnych nuncjuszów apostolskich w Warszawie. Zainteresowanie Mołdawią nie osłabło bynajmniej z chwilą wybuchu powstania Bohdana Chmielnickiego w 1648 r., które dezaktualizowało plany wojny tureckiej. Pamiętamy zresztą, iż funkcjonowały one nadal na dworze brata zmarłego Władysława IV, Jana Kazimierza, będąc jedną z propozycji rozwiązania problemu kozackiego poprzez danie ujścia zaporoskiemu żywiołowi w kierunku Turcji. Nie dalej przecież jak na początku XVII w. pchnięcie Zaporożców na bezkresne obszary państwa moskiewskiego w okresie wielkiej smuty pozwoliło uwolnić Ukrainę od zaczynającej się już wówczas plagi powstań kozackich, zapoczątkowanych wystąpieniami Krzysztofa Kosińskiego i Semena Nalewajki w latach 90. XVI w. Co więcej, to właśnie udział Kozaków pod wodzą Piotra Konaszewicza-Sahajdacznego w wyprawie na Moskwę w 1618 r. umożliwił przełamanie impasu, wynikłego z braku wystarczających sił własnych ekspedycji królewicza Władysława i podjęcie próby zdobycia stolicy carów. Czemuż teraz miałoby być inaczej? Ten ponętny plan rozwiązania kryzysu na Ukrainie runął dopiero wraz ze śmiercią jego głównego promotora, kanclerza wielkiego koronnego Jerzego Ossolińskiego

* Dariusz Milewski - dr historii, adiunkt w Instytucie Nauk Historycznych na Wydziale Nauk Historycznych i Społecznych Uniwersytetu Kardynała Stefana Wyszyńskiego w Warszawie. 
w dniu 9 sierpnia 1650 r. oraz zdradzieckim - z polskiego punktu widzenia, rzecz jasna - najazdem Chmielnickiego na Mołdawię, będącą nadal najpoważniejszym potencjalnym sojusznikiem Polski w przewidywanej krucjacie antytureckiej. Najazd, przedsięwzięty we wrześniu 1650 r. przez Kozaków do spółki z Tatarami, nie tylko pozwolił Chmielnickiemu uniknąć udziału w planowanej przez Chanat Krymski ekspedycji przeciw Moskwie - która byłaby Polakom bardzo na rękę, jako że poskromiłaby groźnego sąsiada i dodatkowo zdyskredytowała Chmielnickiego w oczach cara, kładąc kres podejmowanym przezeń próbom antypolskiego porozumienia z Kremlem - ale jednocześnie odsłonił podwójną grę hetmana kozackiego wobec Warszawy i przekreślił rachuby na wciągnięcie Zaporożców do wojny z Turcją. Zamiast tego, miało dojść do decydującej rozgrywki na stepach Ukrainy w roku następnym, 1651. W ten sposób sprawy mołdawskie znów wpłynęły na arenę wydarzeń, rozgrywających się między Warszawą, Stambułem, Bachczysarajem i Czehryniem, co najmniej jako probierz politycznych zamierzeń i realnych możliwości ich urzeczywistnienia przez wszystkie strony konfliktu. Probierz - jak się okazało - niezawodny.

Zobaczmy zatem, co z wydarzeń mołdawskich docierało do nuncjuszów apostolskich w Warszawie - przedstawicieli jedynego chyba państwa, obok toczącej właśnie wojnę z Turcją Wenecji, które było realnie zainteresowane we wciągnięciu Rzeczypospolitej w zmagania z Półksiężycem - a zarazem co uznawali za stosowne przekazać w swych relacjach do Rzymu. W latach 1648-1653, kiedy ważyły się losy Mołdawii i jej stanowiska w konflikcie polsko-kozackim, Stolicę Apostolską w Warszawie reprezentowało dwóch nuncjuszów: Giovanni de Torres i - od września 1652 r. - Pietro Vidoni ${ }^{1}$. Ich korespondencję dyplomatyczną opublikował historyk ukraiński Stefan Tomasziwskij w 1924 r. i ona stanie się podstawą naszych badań ${ }^{2}$. Zapoznamy się najpierw z treścią poszczególnych raportów, wyławiając z nich wiadomości dotyczące Mołdawii, a następnie spróbujemy wyciągnąć ogólne wnioski.

W relacji z 6 lutego $1648 \mathrm{r}$. Giovanni de Torres donosi, powołując się na zeznania zbiega tatarskiego, który przeszedł przez Mołdawię, iż hospodar Bazyli Lupul kontynuuje starania o wydobycie córki, Domny Rozandy, z rąk tureckich i wysłał w tym celu umyślnego posła do Stambułu. Ten jednak został zabity z rozkazu sułtana, co napełniło hospodara obawą o własną osobę ${ }^{3}$. Miesiąc później przyszły wiadomości od hetmana wielkiego koronnego Mikołaja Potockiego, kierowane na ręce kanclerza Jerzego Ossolińskiego, a pochodzące ze Stambułu - niestety nie znamy źródła informacji hetmana - iż sułtan polecił paszy Sylistrii i chanowi krymskiemu, aby siłą doprowadzili nad Bosfor obu hospodarów, mołdawskiego Bazylego Lupula i wołoskiego Mateusza Basaraba. Ich miejsce w Jassach i Bukareszcie mieli zająć paszowie tureccy ${ }^{4}$. Byłoby to więc nawiązanie

${ }^{1}$ Giovanni de Torres (1605-1662), nuncjusz w Polsce w latach 1645-1652.

${ }^{2}$ Ватиканськи матеріали до історії України, t. 1 - Донесення римських нуниіїв про Україну 1648-1657, w: Жерела до історії Украӥни, wyd. С. Томашівський, t. 16. Львів 1924 (dalej: Ватиканськи матеріали).

${ }^{3}$ G. de Torres do Rzymu, Warszawa, 6 II 1648 r., Ватиканськи матеріали, nr 6, s. 4-5.

${ }^{4}$ G. de Torres do Rzymu, Warszawa, 5 III 1648 r., Ватиканськи матеріали, nr 9, s. 5-6. 
do koncepcji Murada III i wielkiego wezyra Sinana-paszy z 1595 r., którzy wobec jawnego buntu ówczesnego hospodara Wołoszczyzny Michała Walecznego i ciągłych niepokojów w Mołdawii, zmierzali do osadzenia na tronie wołoskim sułtańskiego faworyta Bogdana i przekształcenia Mołdawii w turecki paszałyk. Dodajmy, że zadanie spacyfikowania Mołdawii również wtedy spoczęło na barkach chana krymskiego i jedynie zbrojna interwencja polska pod wodzą hetmana Jana Zamoyskiego pokrzyżowała plany tureckie. Pamięć o próbie ich realizacji sprawiała jednak, że była to groźba nader realna 5 .

Kolejne wiadomości z Mołdawii w korespondencji nuncjusza papieskiego pochodzą dopiero z lata 1648 r., kiedy Ukraina na dobre już stanęła w ogniu powstania kozackiego. Oto w raporcie z 29 sierpnia $1648 \mathrm{r}$. Giovanni de Torres donosi o przyjściu z Mołdawii wieści o rewolcie janczarów i spahii w Stambule, w wyniku której obalono sułtana Ibrahima i osadzono na tronie jego syna Mehmeda (którego nuncjusz zwie notabene błędnie Muradem). Chodzi tu niewątpliwie o list hospodara Bazylego Lupula do Mikołaja Ostroroga, wysłany z Jass 16 sierpnia 1648 r., w którym hospodar opisuje powyższe wydarzenia ${ }^{6}$. W dalszym ciągu dyplomata papieski skupia się raczej na zabiegach księcia siedmiogrodzkiego Jerzego I Rakoczego, zmierzających do osiągnięcia tronu polskiego dla jednego z synów, do czego miały mu posłużyć korupcja, przejście na katolicyzm i poślubienie królowej-wdowy przez elekta, a w ostateczności sojusz z Kozakami i zajęcie Krakowa siłą. Mołdawia ginie w tym burzliwym okresie elekcji królewskiej w Polsce z oczu de Torresa, aczkolwiek nie omieszkał on wspomnieć o niejasnych do końca uprawnieniach Bazylego Lupula, jakie miał on otrzymać od sułtana w kwestii pośrednictwa między Chmielnickim a Polakami .

Nowy rok 1649 przyniósł w korespondencji Giovanniego de Torresa te same obawy o udział Mołdawii w sojuszu z Kozakami i Siedmiogrodem przeciwko

${ }^{5}$ Szerzej o ówczesnych planach tureckich i kampanii 1595 r. w Mołdawii zob. T. Korzon, Dzieje wojen i wojskowości w Polsce, t. 2. Kraków 1912, s. 111-117 i Z. Spieralski, Awantury mołdawskie, Warszawa 1967, s. 145-146. Autorzy rumuńscy, V. Panaite, Pace, război şi comert în Islam. Ţările române şi dreptul otoman al popoarelor (secolele XV-XVII), Bucureşti 1997, s. 377-380 i M. Maxim, An Introduction to the Juridical-Legal Foundations of the Relations between the Ottoman Empire and the Romanian Principalites, w: M. Maxim, Romano-Ottomanica. Essays \& Documents from the Turkish Archives, "Analecta Isisiana”, t. 58, Istanbul 2001, s. 15, są zdania, że mimo możliwości aneksji, Turcy utrzymywali księstwa naddunajskie jako strefę buforową, oddzielającą ich od państw chrześcijańskich.

${ }^{6}$ G. de Torres do Rzymu, Warszawa, 29 VIII 1648 r., Ватиканськи матеріали, nr 34, s. 19-20. Wspomniany list hospodara: Bazyli Lupul do M. Ostroroga, Jassy, 16 VIII 1648 r., w: Documente privitoare la istoria României culese din arhivele polone. Secolul al XVII - lea, wyd. I. Corfus, Bucureşti 1983, nr 90, s. 157.

${ }^{7}$ G. de Torres do Rzymu, Warszawa, 10 X 1648 r., Ватиканськи матеріали, nr 44, s. 26. Czytamy tam: „Dicesi che il Crimileski capo de Cosacchi habbia havuta la patente del palatino di Valacchia dal Turco con obligo di render feudatarii al Suo imperio tutti gli acquisti, che farà in questo regno". Doniesienia nuncjusza o zabiegach Rakoczego i jego machinacjach z Chmielnickim znajdujemy w raportach z 5 IX, nr 35, s. 20 oraz 3 X, nr 41, s. 24 i 10 X, nr 42, s. 25. 
Polsce, które podzielali współcześni polscy obserwatorzy wydarzeń ${ }^{8}$. Oto w relacji z 20 marca 1649 r. nuncjusz donosi, iż Chmielnicki wysłał posłów do Jerzego II Rakoczego, podejrzewając zarazem, iż do tych dwóch jawnych wrogów Rzeczypospolitej dołączą hospodarowie Wołoszczyzny i Mołdawii, a nawet car moskiewski, którego miałby nakłonić do sojuszu patriarcha Aleksandrii. Byłaby to zatem prawdziwa liga schizmatyków i heretyków przeciw katolickiemu królowi polskiemu, co nie mogło ujść uwadze nuncjusza oraz Stolicy Apostolskiej. Dodajmy na marginesie, że z uwagi na związki lenne łączące Wołoszczyznę z Siedmiogrodem, udział Mateusza Basaraba w takim przymierzu nie byłby niczym dziwnym, choć jego kraj nie sąsiadował z Rzecząpospolitą. Nie przeszkodziło to wojskom wołoskim posiłkować zaprzyjaźnionego Rakoczego w jego najeździe na Polskę w 1657 r., aczkolwiek wtedy związki Wołoszczyzny i Siedmiogrodu były jeszcze silniejsze i nacechowane wyraźną dominacją siedmiogrodzką ${ }^{10}$. Zupełnie inaczej rzecz miała się z Bazylim Lupulem, który dotychczas żył w nieprzyjaźni ze wszystkimi potencjalnymi sojusznikami przeciwko Polsce, a właśnie w Rzeczypospolitej upatrywał oparcia i zabezpieczenia przed zakusami Kozaków i Siedmiogrodzian. Jednakże po klęskach 1648 r. Rzeczpospolita zdawała się być bezsilna i hospodar mołdawski musiał prowadzić podwójną grę, do czasu rozstrzygnięcia konfliktu na polu bitwy ${ }^{11}$. A ponieważ był mistrzem w tej dziedzinie, czego dowiódł lawirując skutecznie przez kilkanaście lat między wrogimi potęgami i rekordowo długo utrzymując się na tronie hospodarskim, nuncjusz apostolski w kolejnych raportach nadal pisał o Lupulu jako przeciwniku Polski. W dniu 10 kwietnia donosił o wysłaniu przez króla Jana Kazimierza do Siedmiogrodu posła Jana Wielopolskiego, który miał odwieść Rakoczego od sojuszu z Chmielnickim - co potwierdza nie tylko niewątpliwą realność takiego zagrożenia, ale i nieustającą obawę dyplomacji papieskiej ${ }^{12}$ - a trzy tygodnie później dał wyraz żywionym

${ }^{8}$ Zob. np. W. Miaskowski do N.N., Nowosiółki, 1 II 1649 r., w: Jakuba Michałowskiego wojskiego lubelskiego, a później kasztelana bieckiego księga pamiętnicza z dawnego rękopisma, będącego własnościa Ludwika hr. Morsztyna, wyd. A. Z. Helcel, Kraków 1864, nr 100, s. 364-365 (dalej: J. Michałowski, Księga pamiętnicza) i A.Kisiel i W. Miaskowski do Jana Kazimierza, Wasilków, 11 II 1649 r., w: Ojczyste spominki w pismach do dziejów dawnej Polski, wyd. A. Grabowski, t. 2. Kraków 1845, nr 2, s. 10 (dalej: Ojczyste spominki).

${ }^{9}$ G. de Torres do Rzymu, Warszawa, 20 III 1649 r., Ватиканськи матеріали, nr 69, s. 37. Zaniepokojony nuncjusz pisał m.in.: „Dicono che li medesimi Cosacchi habbiano mandati ambasciatori al Transilvano, il quale ne tiene de gl'altri suoi appresso il Chimilinski; e si dubita d'una cospiratione e lega di questi uniti col Vallacco e Moldavo contro la Polonia, e non senza qualche sospetto, che vi possano tirar anche il Moscovita per istipatione del patriarca d’Allessandria, che, come si disse, già con altre lettere si portò in Mosca con diligenza doppo d haver trattato molto strettamente col sudetto Chimilinski".

${ }^{10}$ Szerzej na temat zdobywania przez Siedmiogród wpływów na Wołoszczyźnie i w Mołdawii w połowie XVII w. zob. J. Demel, Historia Rumunii, Warszawa 1970, s. 199-202.

${ }^{11}$ Politykę Bazylego Lupula wobec Polski i Kozaków w pierwszym okresie powstania Bohdana Chmielnickiego i rzeczywiste cele hospodara w przededniu kampanii 1649 r. omawia D. Milewski, Mołdawia a Rzeczpospolita w latach 1648-1649, „Biblioteka Poznańskiego Humanistycznego Towarzystwa Naukowego", Poznań 2003, t. 2, s. 9-23.

${ }^{12}$ G. de Torres do Rzymu, Warszawa, 10 IV 1649 r., Ватиканськи матеріали, nr 71, s. 38. 
na dworze królewskim obawom o postawę hetmana polnego litewskiego Janusza Radziwiłła. Obawa ta, podsycana przez osobistą niechęć króla do litewskiego magnata, kazała podejrzewać tego wyznawcę kalwinizmu i zięcia Bazylego Lupula - obie te cechy wyróżnił Giovanni de Torres jako obciążające Radziwiłła, czym dał wyraz ogarniającej, przynajmniej nuncjusza, gorączce wojny religijnej - o konszachty z Chmielnickim. Asumpt do tych podejrzeń miała dać przejęta instrukcja hetmana kozackiego dla posłów do Rakoczego ${ }^{13}$. Dodajmy, że oskarżenia o konszachty z Siedmiogrodem padały jesienią $1648 \mathrm{r}$. także pod adresem księcia wojewody ruskiego Jeremiego Wiśniowieckiego, którego Jan Kazimierz również nie darzył bynajmniej sympatią i także one zostały skrzętnie odnotowane przez dyplomatę papieskiego ${ }^{14}$. Wysuwane wiosną 1649 r. obawy w stosunku do zachowania się Janusza Radziwiłła okazały się - jak wiemy - bezpodstawne, a hetman dowiódł swej wierności dla Rzeczypospolitej gromiąc wojska kozackie Michała Krzyczewskiego w bitwie pod Łojowem 31 lipca 1649 r. Warto jednak zwrócić uwagę, iż fakt związków rodzinnych, łączących Radziwiłła z Lupulem, zadziałał w tym okresie na niekorzyść hetmana litewskiego. To zaś ponownie dowodzi, jak mistrzowsko grał wtedy hospodar mołdawski rolę sojusznika kozackiego.

Kolejną odsłoną w tym politycznym teatrze było przyjęcie w Jassach, jakie przebiegły hospodar zorganizował posłom Jerzego Rakoczego, zmierzającym na Ukrainę do Chmielnickiego. Wzniesiono tam mianowicie - jeśli nie z inicjatywy, to na pewno za przyzwoleniem hospodara - publiczny toast za wyniesienie brata Rakoczego na trony Polski i Węgier. Owo mołdawskie „vivat!” - niewykluczone, że spełniane przednim mołdawskim winem - dotarło do uszu de Torresa i pobudziło go do napisania alarmistycznego raportu do Kurii Rzymskiej w dniu 15 maja 1649 r., a więc w dwa tygodnie po wysunięciu oskarżeń pod adresem zięcia Lupulowego ${ }^{15}$. Było to jednak ,vivat” tyleż głośne, co i gołosłowne, nie przeszkodziło bowiem $\mathrm{w}$ najmniejszym stopniu hospodarowi pośredniczyć - w tym samym czasie! - w pertraktacjach dotyczących wykupienia hetmanów koronnych z niewoli tatarskiej (przypomnijmy, że właśnie w Jassach miała nastąpić transakcja przekazania okupu Tatarom $)^{16}$. Rzecz ta zdawała się być już tak bliska urzeczywistnienia, iż w kolejnym raporcie, pisanym zresztą tego samego dnia, Giovanni de Torres podał wyjście na wolność zajadłego wroga Kozaków, hetmana wielkiego koronnego Mikołaja Potockiego, jako fakt dokonany ${ }^{17}$. I dopiero osobista interwencja Chmielnickiego u chana Islam Gereja, o której dowiadujemy się od nuncjusza z jego relacji z 29 maja, zapobiegła uwolnieniu Potockiego - hetman kozacki ani myślał dopuścić, by główny rzecznik zdławienia powstania kozackiego przy pomocy siły oręża, a zarazem wódz armii koronnej, wrócił

${ }^{13}$ G. de Torres do Rzymu, Warszawa, 1 V 1649 r., Ватиканськи матеріали, nr 74, s. 39.

${ }^{14}$ Zob. G. de Torres do Rzymu, Warszawa, 26 XII 1648 r., Ватиканськи матеріали, nr 60, s. 34, gdzie porusza kwestię rzekomej darowizny na rzecz księcia Jeremiego 100 tys. florenów przez Rakoczego i stanowcze protesty Wiśniowieckiego w tej sprawie.

${ }^{15}$ G. de Torres do Rzymu, Warszawa, 15 V 1649 r., Ватиканськи матеріали, nr 76, s. 40.

${ }^{16}$ Ł. Miaskowski do NN., Kamieniec Podolski, 3 V 1649 r., w: Ojczyste spominki, nr 8, s. 18.

${ }_{17}$ G. de Torres do Rzymu, Warszawa, 15 V 1649 r., Ватиканськи матеріали, nr 77, s. $40-41$. 
na Ukrainę w przeddzień nowej kampanii ${ }^{18}$. W tej sytuacji nietrudno ocenić, co było istotniejsze w poczynaniach Bazylego Lupula - czy głośne wiwaty na cześć Siedmiogrodzian i Kozaków, czy cicha, wręcz krecia robota, jaką wykonywał na korzyść Polaków.

Kampania 1649 r. - przed którą hospodar mołdawski lojalnie informował Polaków o siłach wojsk kozacko-tatarskich ${ }^{19}$ - zaowocowała ugodą zborowską, tworzącą 40-tys. rejestr kozacki oraz odnowieniem na dworze królewskim planów wojny tureckiej. Ich odbicie znajdujemy w korespondencji nuncjusza papieskiego, który w przededniu rozpoczęcia sejmu informował Kurię Rzymską o planach Jana Kazimierza, zakładających uderzenie na Turcję z siłami owych 40 tys. Kozaków oraz 30 tys. wojsk własnych ${ }^{20}$. Liczono w Polsce oczywiście na współdziałanie Wenecji, do której pojechał jako ambasador biskup kujawski Mikołaj Gniewosz. Dotarł on 23 października 1649 r. do Wiednia, gdzie przeprowadził rozmowy na ten temat z nuncjuszem Giovannim Battistą Viscontim i pozyskał jego poparcie dla tych planów - które z kolei wyraziło się w staraniach nuncjusza u posła weneckiego w Wiedniu, Niccolò Sagredy, zmierzających do wysłania przez Wenecję ambasadora do Polski na sejm i udzielenia królowi subsydiów wojennych ${ }^{21}$. Te świetne plany pokrzyżowała perfidia Chmielnickiego, na którą uskarżał się Jan Kazimierz w liście do nuncjusza papieskiego w Wiedniu z dnia 12 grudnia 1649 r. Według króla, hetman kozacki słał pokorne listy i zapewniał o chęci wojny z Turcją, a tymczasem znosił się z Rakoczym i wysłał posła do Lupula, żeby go przeciągnąć na swoją stronę, przeciw Polsce i wymóc na nim, by się otwarcie zdeklarował, czy chce być Chmielnickiemu przyjacielem czy wrogiem. Wieści te pozyskał król z awiz i listów, przejętych w Mołdawiii ${ }^{22}$. W tym kontekście wraca też Mołdawia w krąg zainteresowań nuncjusza de Torresa, który 18 grudnia donosił do Rzymu, iż mimo zapewnień Chmielnickiego o jego uległości, wiadomo od szlachcica, wysłanego do Mołdawii w celu prowadzenia pertraktacji z Tatarami na temat uwolnienia jeńców, iż hetman kozacki czyni usilne starania, by znów sprowadzić Tatarów do Polski ${ }^{23}$. Mołdawia funkcjonuje tu zatem jako źródło informacji o poczynaniach kozackich, pozwalające zweryfikować zapewnienia Chmielnickiego o jego wierności względem Rzeczypospolitej.

Tymczasem dobiegały końca starania o uwolnienie hetmanów koronnych z niewoli tatarskiej. To właśnie nuncjusz de Torres informuje nas w swym liście z 26 lutego 1650 r., iż Mikołaj Potocki wyszedł z niewoli, dawszy w zakład syna i bawił w gościnie u hospodara Bazylego Lupula w Jassach. Stamtąd wysłał 3 lu-

18 G. de Torres do Rzymu, Warszawa, 29 V 1649 r., Ватиканськи матеріали, nr 80, s. $42-43$.

${ }^{19}$ J. Kutnarski do Ł. Miaskowskiego, Jassy, 28 VI 1649 r., w: Ojczyste spominki, nr 31, s. 51.

${ }^{20}$ G. de Torres do Rzymu, Warszawa, 20 XI 1649 r., Ватиканськи матеріали, nr 110, s. 61 62.

${ }^{21}$ N. Sagredo do Siniorii, Wiedeń, 23 X 1649 r., w: Жерела до історії Украӥни-Руси, wyd. М. Кордуба, t. 12. Львів 1911 (dalej: Жерела), nr 87, s. 122 і N. Sagredo do Siniorii, Wiedeń, 30 X 1649 r., Жерела, nr 88, s. 122-123.

${ }^{22}$ Jan Kazimierz do G. B. Viscontiego, Warszawa, 12 XII 1649 r., Жерела, nr 96, s. 124-125.

${ }^{23}$ G. de Torres do Rzymu, Warszawa, 18 XII 1649 r., Ватиканськи матеріали, nr 115, s. 63. 
tego list, zawiadamiający o swym rychłym przyjeździe do Lwowa ${ }^{24}$. Interesowała też nuncjusza rola Mołdawii w planowanej wojnie tureckiej, do której - przypomnijmy - starano się pozyskać nawet Tatarów. Chan tatarski czynił Warszawie pewne nadzieje, lecz jednocześnie - jak dowiedział się nuncjusz - poseł tatarski w Stambule obiecał wszelką pomoc sułtanowi. O tej gotowości Tatarów powiadomiono niezwłocznie w Stambule agentów obu hospodarów, wzywając zarazem Basaraba i Lupula, żeby przybyli jak najszybciej przed oblicze sułtana i złożyli mu osobisty hołd ${ }^{25}$. Wskazuje to wyraźnie na nieufność Turków wobec obu hospodarów, aczkolwiek nuncjusza interesowała w tym przypadku raczej podwójna gra Tatarów - miał jeszcze nadzieję, że to Turków zwodzą. Postawy hospodarów był, jak widać, pewien.

Obaj dali zresztą już wkrótce dowody swej życzliwości, donosząc o kurierach, kursujących między Rakoczym a Chmielnickim przez Mołdawię i Wołoszczyznę - choć zdecydowanie najczęściej szlak musiał wieść przez państwo Bazylego Lupula - oraz o związanych $\mathrm{z}$ tym własnych przeczuciach nieszczerości hetmana kozackiego. Informacji takiej nie omieszkał zanotować i przekazać do Rzymu nasz nuncjusz, co stało się w liście z 30 kwietnia $1650 \mathrm{r}^{26}$ Mimo wszystko, w Polsce nie rezygnowano z pomysłu wojny tureckiej, a sam Bazyli Lupul zaczął urastać do jednej $\mathrm{z}$ ważniejszych figur w projektowanej wyprawie. Oto w relacji z 4 czerwca 1650 r. Giovanni de Torres pisze, iż wprawdzie Tatarzy pozostaną neutralni w wojnie z Turcją - co byłoby już jakimś sukcesem - lecz dadzą Kozakom wolne przejście, aby ci mogli pomaszerować tam, dokąd król ich zawezwie. Ponadto myśli się w Warszawie nad pozyskaniem 20 tys. wojsk cudzoziemskich, nad którymi komendę miałby objąć nie kto inny, ale właśnie hospodar mołdawski. On sam miałby wystawić 40 tys. żołnierzy, do czego doszłoby 50 tys. Kozaków Chmielnickiego, a wreszcie król z wojskiem koronnym. Wszystkie te siły miałyby połączyć się na Wołoszczyźnie i stamtąd - zapewne już pod naczelnym dowództwem króla polskiego - rozpocząć zwycięską kampanię przeciwko Turkom. Koszty tej wojny obliczał nuncjusz na milion talarów rocznie na utrzymanie samego wojska cudzoziemskiego, jednak w perspektywie wspólnego z Wenecją uderzenia na państwo Osmanów i niechybnego, i ostatecznego pognębienia ich potęgi, była to dla dyplomaty papieskiego suma możliwa do przyjęcia, skoro taką koncepcję przedstawił Kurii Rzymskiej ${ }^{27}$. Wiemy oczywiście, że były to gruszki

${ }^{24}$ G. de Torres do Rzymu, Warszawa, 26 II 1650 r., Ватиканськи матеріали, nr 135, s. 74.

${ }^{25}$ G. de Torres do Rzymu, Warszawa, 16 IV 1650 r., Ватиканськи матеріали, nr 142, s. $78-79$.

${ }^{26}$ G. de Torres do Rzymu, Warszawa, 30 IV 1650 r., Ватиканськи матеріали, nr 145, s. $80-81$.

${ }^{27}$ G. de Torres do Rzymu, Warszawa, 4 VI 1650 r., Ватиканськи матеріали, nr 149, s. 82-83. Czytamy tam m.in.: „Qui sinhora si sta in deliberatione di tirarvi i Cosacchi et i Tartari, e di questi s'aspetta un 'ambasciata in breve con un gran segreto, et in evento, che detti Tartari non fossero per invadere il Turco, d haverli neutrali e di far haver anche licenza libera alli Cosacchi, per che, non ostante la lega fra di loro, questi possano andar, dove il proprio re li chiamerà, con le loro armi. Si pensa cogl'aiuti de` stranieri di formar un essercito di $20 \mathrm{~m}$. persone e di darne il comando al principe di Moldavia, che havrà de suoi proprii altri $40 \mathrm{~m}$. huomini et è molto dovizioso. In un medesimo tempo, che si muova il Chimilinski per un`altra parte con I suoi $50 \mathrm{~m}$. Cosacchi e con I Tartari, 
na wierzbie, bo ani szlachta nie kwapiła się płacić podatków na wojnę turecką, ani Chmielnicki czy Tatarzy brać w niej udziału, ani też sam Lupul, na którego tak bardzo liczono i który był być może całej sprawie najbardziej przychylny, nie miał takich możliwości, jakie mu przypisał w swym entuzjastycznym wywodzie nuncjusz papieski. Cała ta polityczna fantastyka interesuje nas jednak o tyle, o ile odsłania przed nami stosunek hospodara mołdawskiego do Rzeczypospolitej oraz jego postrzeganie w Warszawie, jakże odległe od alarmistycznych wieści sprzed roku, kiedy posądzano go o sojusz z Rakoczym i Chmielnickim przeciw Polsce. Przy okazji możemy też zaryzykować twierdzenie, iż plan powierzenia Bazylemu Lupulowi dowództwa nad znaczną częścią wojsk był chytrym sposobem spętania hospodara tym zaszczytem i uniemożliwienia mu wycofania się z całej akcji, jak to się stało w $1646 \mathrm{r}$.

Już w miesiąc później, 3 lipca, pisał Giovanni de Torres do Rzymu - powołując się na otrzymane przez hetmana M. Potockiego wieści znad Bosforu - iż w związku z niepokojem, jaki wywołało w Stambule pojawienie się floty weneckiej w Dardanelach, sułtan napisał do chana, by ten z całą siłą wyprawił się do Mołdawii i na Wołoszczyznę, a całą zdobycz odesłał czym prędzej do stolicy Turcji ${ }^{28}$. Taka reakcja sułtana - czy raczej rządzącego w jego imieniu wielkiego wezyra byłaby, wobec wciąż żywych pomysłów wciągnięcia Rzeczypospolitej do wojny z Turcją, tyleż wyrazem zaufania do Tatarów, co braku pewności co do postawy hospodarów. Jednakże - zdaniem dyplomaty papieskiego - chan nie uczyni nic, dopóki sprawy ligi antytureckiej są w zawieszeniu i nie powróci goniec, wysłany przez króla do chana, Chmielnickiego i Bazylego Lupula, który miał otrzymać od nich ostateczne decyzje ${ }^{29}$.

Jak wiemy, zamiast wspólnego pochodu na Turków, Kozacy i Tatarzy uderzyli we wrześniu 1650 r. na jedynego pewnego sojusznika Rzeczypospolitej w tym regionie, Bazylego Lupula. Przypomnijmy, że powodem do najazdu stało się dla Chmielnickiego dążenie do uniknięcia konieczności wzięcia udziału w tatarskiej wyprawie na Moskwę, dla Tatarów zaś chęć pomszczenia porażki, jakiej doznał z rąk Lupula jeden z ich oddziałów w czasie jesiennego odwrotu z Polski w 1648 r. Nuncjusz papieski zareagował na te wydarzenia, donosząc w liście z 16 września 1650 r., kierowanym tym razem do posła weneckiego w Wiedniu, Niccolò Sagredy, iż chodzą wieści, jakoby Chmielnicki towarzyszył chanowi w najeździe na Mołdawię $e^{30}$. Bardziej precyzyjne informacje zawarł w raporcie do Kurii Rzymskiej z dnia następnego, powołując się na list od Mikołaja Potockiego. Zgodnie z

se sarà possibile d`haverli, se il re con un altro essercito si muoverà ancor esso e s’accamperà nella Vallachia. Questi par che sieno i disegni di qua, ma par anche che sieno bisognosi d’aiuti alieni, e massime di danaro, cioè intorno ad un millione di tallari per mantenimento d'un anno dell 'essercito forestiero".

${ }^{28}$ G. de Torres do Rzymu, Warszawa, 3 VII 1650 r.,Ватиканськи матеріали, nr 154, s. 86.

${ }^{29}$ G. de Torres do Rzymu, Warszawa, 23 VII 1650 r., Ватиканськи матеріали, nr 157, s. 87. $\mathrm{Z}$ listu de Torresa nie wynika, czy chodzi o jednego gońca, czy też do każdego z adresatów posłano innego człowieka. Pisząc o jego powrocie, nuncjusz używa sformułowania „il ritorno d’un espresso mandato in diligenza al Chan, al Chimilinski et al Moldavo".

${ }^{30}$ G. de Torres do N. Sagredy, Warszawa, 16 IX 1650 r., Жерела, nr 122, s. 135. 
nim relacjonuje, iż Tatarzy najechali Mołdawię i między inną zdobyczą zagarnęli słynną i liczną stadninę hospodara. Chmielnicki miał asystować Tatarom, a nad Dniestrem założyć obóz, złożony z 40 tys. czerni pod wodzą pułkownika bracławskiego Daniły Nieczaja, wzmocniony 10 tys. Kozaków, którzy mieli powstrzymać hetmana koronnego w razie chęci udzielenia przezeń pomocy hospodarowi ${ }^{31}$. Wreszcie tydzień później nuncjusz donosił, iż potwierdziło się wszystko, co napisał o najeździe tatarsko-kozackim na Mołdawię, a także dodał, iż Chmielnicki nie miał specjalnego rozkazu Turków, a dla zaprzysiężenia własnej wierności wysłał umyślnego posła do Stambułu. To - zdaniem nuncjusza - potwierdza, iż hetman kozacki działał z własnej inicjatywy. Co do Mikołaja Potockiego, de Torres donosił, iż stał on nadal z wojskiem pod Kamieńcem Podolskim, nie interweniując w obronie hospodara ${ }^{32}$.

W kolejnym raporcie, pisanym 1 października 1650 r., nuncjusz donosił już o zawarciu porozumienia między Tatarami a hospodarem mołdawskim. Skoro bowiem orda i towarzyszący jej Kozacy nasycili swą chciwość złupieniem znacznej części Mołdawii, Bazyli Lupul dla uniknięcia dalszych klęsk okupił im się sumą 120 lub 200 tys. talarów - nuncjusz nie wiedział, która cyfra jest prawdziwa - i tym sposobem skłonił ich do opuszczenia kraju. To z kolei wzbudziło zawiść Chmielnickiego, który nie mógł najechać kraju, a zapewne żywi złe zamiary wobec Mołdawii. Hetman Potocki wymienił z nim oficjalne listy w tej sprawie, co skłoniło nuncjusza do wyrażenia wiary, iż ustabilizuje się pokój i uda się zjednoczyć siły przeciw wspólnemu wrogowi (nie wymienionemu z imienia, ale bez wątpienia chodzi o sułtana ${ }^{33}$. Jak wiemy, Chmielnicki rzeczywiście usypiał listami czujność hetmana koronnego, posuwając się nawet w swej przebiegłości do prośby o udzielenie mu pomocy wojskowej w tej wyprawie, bo wszak jest poddanym Jego Królewskiej Mości(!). Mikołaj Potocki oczywiście odmówił, uzasadniając to faktem, iż Chmielnicki podjął wyprawę bez wiedzy Rzeczypospolitej ${ }^{34}$. Nie przeszkodziło to hetmanowi kozackiemu wysłać do wodza wojsk polskich kolejnego listu, w którym zapewniał go, że dokonany właśnie najazd na sojusznika Rzeczypospolitej nie był niczym innym, jak wstępem do tworzenia ligi antytureckiej $^{35}$. Nie wiemy, czy sam Chmielnicki spodziewał się, że ktokolwiek w Polsce uwierzy w tak bezczelne wykręty, ale przyznać musimy, iż znalazły one odbicie w przywołanej przed chwilą korespondencji Giovanniego de Torresa. Nuncjusz

${ }^{31}$ G. de Torres do Rzymu, Warszawa, 17 IX 1650 r., Ватиканськи матеріали, nr 164, s. $90-91$.

${ }^{32}$ G. de Torres do Rzymu, Warszawa, 24 IX 1650 r., Ватиканськи матеріали, nr 165, s. 91.

${ }^{33}$ G. de Torres do Rzymu, Warszawa, 24 IX 1650 r., Ватиканськи матеріали, nr 166, s. 91. Hospodar wręczył Tatarom 120 tys. talarów okupu - zob. K. Korycki do J. Radziwiłła, Warszawa, 1 X 1650 r., w: Diariusz kancelaryjny Janusza Radziwiłła, Archiwum Główne Akt Dawnych w Warszawie, Archiwum Radziwiłłów dz. VI, nr 36, s. 342.

${ }^{34}$ Lenkiewicz do S. Pawszy, Zahorzany, 26 IX 1650 r., tamże, s. 333.

${ }^{35}$ B. Chmielnicki do M. Potockiego, Jampol, 28 IX 1650 r., w: Документи Богдана Хмельнииького 1648-1657, wyd. I. Крип якевич, Київ 1961, nr 117, s. 188-189. Zob. też W. Serczyk, Na płonacej Ukrainie. Dzieje Kozaczyzny 1648-1651, Warszawa 1998, s. 312. 
apostolski, reprezentując stanowisko Rzymu, któremu zależało na pokonaniu Turków, podchwytywał każdą przesłankę, która pozwalała mu podtrzymać nadzieję na wojnę z Półksiężycem.

Twarda rzeczywistość kazała jednak rychło pożegnać się papieskiemu dyplomacie z marzeniami o wciągnięciu Kozaków do wojny z Turcją, a zatem i z samą tą wojną. Zaledwie tydzień po wyrażonych nadziejach w tej sprawie, pisał już Giovanni de Torres do Rzymu o swej poufnej rozmowie z królem, w której polski monarcha oznajmił mu o swym zamiarze zaatakowania zimą Chmielnickiego z trzech stron - od Litwy, Korony i Mołdawii, z której spodziewał się posiłków na odwetową wyprawę przeciw Kozakom ${ }^{36}$. Możemy śmiało przypuszczać, iż w rozwianiu się złudzeń nuncjusza co do postawy Chmielnickiego poważną rolę odegrał też powrót ze Lwowa wysłannika ambasadora weneckiego w Wiedniu, Alberta Viminy, o czym nuncjusz donosił tego samego dnia ${ }^{37}$. Vimina posłował latem do Chmielnickiego, chcąc go w imieniu Republiki św. Marka nakłonić do wzięcia udziału w wojnie z Turcją. Hetman kozacki oczywiście nie odmówił, ale zasłonił się grożącym mu rzekomo niebezpieczeństwem ze strony Polski, które uniemożliwia mu podjęcie wyprawy na Turcję ${ }^{38}$. Przyjął za to w dniu 30 lipca 1650 r. ofertę pomocy ze strony sułtana, wyrażoną przez czausza Osmana agę, byleby tylko kontynuował wojnę z Polską ${ }^{39}$. Wobec tych faktów misja Alberta Viminy spełzła na niczym, a jej fiasko musiało zdecydować o postrzeganiu sprawy kozackiej także przez nuncjusza papieskiego.

Odtąd uwaga Giovanniego de Torresa koncentrować się będzie wokół przygotowań do rozprawy z Chmielnickim i w tym kontekście będzie on też patrzył na Mołdawię. Od momentu bowiem, kiedy przymuszony przez Kozaków hospodar zgodził się wydać córkę za Tymofieja Chmielnickiego - o czym nuncjusz poinformował Kurię Rzymską już 15 października ${ }^{40}$ - obie strony uważały Mołdawię za swego sojusznika. Bazyli Lupul ani myślał trwać dobrowolnie w wymuszonym sojuszu z Czehryniem i ta jego postawa nie uszła uwadze de Torresa. Oto 22 października donosił on, iż hospodar mołdawski chce wziąć zbrojny odwet na Chmielnickim i Tatarach. Ponieważ sam ma jednak tylko 6 tys. żołnierzy - a nie 40 tys., jak to jeszcze na początku czerwca chciał widzieć nuncjusz papieski! zwrócił się o pomoc do Rakoczego oraz do swego zięcia, hetmana polnego litewskiego Janusza Radziwiłła. Przy okazji de Torres doniósł też o planowanej aukcji

${ }^{36}$ G. de Torres do Rzymu, Warszawa, 8 X 1650 r., Ватиканськи матеріали, nr 169, s. 92.

${ }^{37}$ G. de Torres do Rzymu, Warszawa, 8 X 1650 r., Ватиканськи матеріали, nr 168, s. 92.

${ }^{38}$ F. von Lisola do Ferdynanda III, Warszawa, 21 VIII 1650 r., Жерела, nr 117, s. 133-134. Kontaktowanie się z Viminą poza plecami Polaków wypomniał Chmielnickiemu hetman wielki koronny - M. Potocki do B. Chmielnickiego, Wielopol, 3 VIII 1650 r., Biblioteka Muzeum Narodowego im. Ks. Czartoryskich w Krakowie, Teki Naruszewicza (dalej: B.Czart., TN), nr 144, s. 935-936. Zob. też T. Chynczewska-Hennel, Alberto Vimina: Ukraina - Kozaczyzna - Bohdan Chmielnicki, w: Національно-визвольна війна украӥнського народу середини XVII століття: політика, військове мистецтво, red. В.А. Смолій, Київ 1998, s. 153.

${ }^{39}$ Relacja o działaniach Chmielnickiego, z miejsca niewiadomego 29 lipca do 6 sierpnia 1650, w: J. Michałowski, Księga pamiętnicza, nr 184, s. 554.

${ }^{40}$ G. de Torres do Rzymu, Warszawa, 15 X 1650 r., Ватиканськи матеріали, nr 170, s. 93. 
wojska koronnego z 12 do 36 tys. żołnierzy i litewskiego z 8 do 12 tys., o czym dowiedział się poufnie ${ }^{41}$. Nasze zdziwienie może wzbudzić na pozór zwrócenie się Lupula z ofertą sojuszu antykozackiego do księcia siedmiogrodzkiego, który wszak pozostawał z Chmielnickim w dobrych stosunkach. Jednakże najazd kozacki na Mołdawię i groźba usadowienia się tam Kozaków zaniepokoiły Jerzego II Rakoczego, gdyż naruszały równowagę w regionie i zagrażały bezpieczeństwu Siedmiogrodu ${ }^{42}$. Hospodar mołdawski dobrze więc wyczuł sytuację, która miała się ziścić - ku jego zgubie zresztą - w 1653 r., kiedy to Siedmiogród i Wołoszczyzna wystąpiły zbrojnie przeciwko kozackiej obecności w Mołdawii.

Tymczasem jednak król polski angażował się w utworzenie ligi przeciw Kozakom $\mathrm{z}$ udziałem obu hospodarów $\mathrm{i}$ - jak dowiadujemy się z kolejnego raportu nuncjusza, pisanego 29 października - Jan Kazimierz zachęcał hospodara wołoskiego, Mateusza Basaraba, do przymierza z Lupulem przeciw Chmielnickiemu ${ }^{43}$. Sam Lupul z kolei obiecał królowi wszystkie swoje siły dla pokonania hetmana kozackiego, co nuncjusz odnotował w następnej relacji4 ${ }^{44}$. Dostrzec zatem możemy w korespondencji Giovanniego de Torresa wyraźne odbicie wzajemnych zabiegów, tak ze strony króla polskiego, jak i hospodara mołdawskiego, mających na celu podtrzymanie sojuszu i zniwelowanie politycznych skutków najazdu tatarsko-kozackiego, a więc niedopuszczenie do dostania się Mołdawii w zakres wpływów Chmielnickiego. Jak pamiętamy, jednym z takich posunięć, mającym utrzymać związki Mołdawii z Rzecząpospolitą, było nadanie indygenatu Bazylemu Lupulowi na grudniowym sejmie $1650 \mathrm{r}^{45}$

Zabiegi te były o tyle konieczne, że również Chmielnicki nie zasypiał gruszek w popiele i starał się urzeczywistnić swój sojusz z Lupulem, przede wszystkim przymuszając go wreszcie do małżeństwa Domny Rozandy z Tymofiejem. Zaniepokojony Giovanni de Torres pisał 26 listopada o przygotowaniach Chmielnickiego do wojny, wśród których hetman kozacki znalazł czas na dogadywanie się z Rakoczym, Lupulem i Basarabem ${ }^{46}$. Donosił też o podejrzeniach króla wobec Janusza Radziwiłła, którego z uwagi na jego związki rodzinne z Lupulem Jan Kazimierz podejrzewał o porozumienie z Chmielnickim. Asumpt po temu dał list hetmana litewskiego do szlachty, w którym pisał on, iż nie nowina to wydawać hospodarom córki za szlachtę polską i jeśli Lupul obiecał córkę synowi Chmielnickiego, musi dotrzymać słowa. Nuncjusz dodał zaraz, iż Janusz Radziwiłł jest

${ }^{41}$ G. de Torres do Rzymu, Warszawa, 22 X 1650 r., Ватиканськи матеріали, nr 171, s. 93-94.

42 Jerzy Rakoczy dał wyraz temu zaniepokojeniu wobec cesarskiego namiestnika na Wegrzech, Paula Pàlffya, o czym donosi ambasador wenecki w Wiedniu - zob. N. Sagredo do Siniorii, Wiedeń, 15 X 1650 r., Жерела, nr 129, s. 140.

${ }^{43}$ G. de Torres do Rzymu, Warszawa, 29 X 1650 r., Ватиканськи матеріали, nr 172, s. 94.

${ }^{44}$ G. de Torres do Rzymu, Warszawa, 5 XI 1650 r., Ватиканськи матеріали, nr 173, s. 94-95.

${ }^{45}$ Diploma Indigenatus Magnifico Vasilio Palatino Moldaviae concessi, w: M. Dogiel, Codex diplomaticus Regni Poloniae et Magni Ducatus Lituaniae, t. 1. Vilnae 1758, s. 621.

${ }^{46}$ G. de Torres do Rzymu, Warszawa, 26 XI 1650 r., Ватиканськи матеріали, nr 176, s. 96. 
głową heretyków litewskich i źródłem złych zamysłów, zwracających się przeciw królowi, a ku hospodarowi mołdawskiemu ${ }^{47}$. Widzimy więc, iż jak bumerang powróciły tu wszystkie oskarżenia z wiosny 1649 r. Zdawałyby się one być uzasadnione w kontekście rozkazów udzielenia pomocy Chmielnickiemu, jakie sułtan wydał chanowi oraz paszy sylistryjskiemu i obu hospodarom, co nuncjusz zanotował w swej relacji z 17 grudnia $^{48}$. Nie omieszkał jednakże donieść Kurii Rzymskiej także o nadaniu indygenatu Lupulowi oraz jego sekretarzowi, Jerzemu Kutnarskiemu - w tym przypadku była to raczej nobilitacja - co w samej Polsce było trzymane w tajemnicy, aby nie zaszkodzić hospodarowi w oczach sułtana i Chmielnickiego ${ }^{49}$.

$\mathrm{Z}$ nowym rokiem $1651 \mathrm{w}$ korespondencji nuncjusza pojawiają się pomyślniejsze wiadomości z Mołdawii. Już 21 stycznia $1651 \mathrm{r}$. donosił on o pogłoskach, według których Porta zabroniła Lupulowi wydawać córkę za Tymofieja, dwa tygodnie później zaś potwierdza to jako rzecz pewną ${ }^{50}$. Wiemy skądinąd, iż Turcy rzeczywiście zawiesili sprawę małżeństwa, chcąc się najpierw przekonać o szczerości Chmielnickiego, który, usadowiwszy się poprzez syna w Mołdawii, stałby się zbyt potężnym lennikiem, aby można było sobie pozwolić na jakiekolwiek ryzyko w stosunku do niego. O takich motywach działania Turków - póki co korzystnego dla Lupula - pisze wprost agent cesarski w Stambule, Rudolf Schmidt, w swej marcowej relacji dla Ferdynanda III. Kozackie obietnice płacenia trybutu i uznania zwierzchności Porty póki co nie wpływały w tej kwestii na zmianę stanowiska sułtana ${ }^{51}$. Nie przeszkadzało to im jednak udzielić Chmielnickiemu poparcia w nadchodzącej rozprawie z Rzecząpospolitą. Giovanni de Torres, powołując się na list Bazylego Lupula z 2 kwietnia 1651 r., pisał, iż przez dwór hospodara $\mathrm{W}$ Jassach przejechał czausz, wiozący szatę i szablę dla Chmielnickiego wraz z rozkazami sułtana do wystąpienia przeciw Polsce i obietnicą pomocy w piechocie. W tymże liście Lupul donosi, że Tatarzy chcą dać Kozakom 15 tys. jazdy, jednakże sam Lupul mniemał, iż ruszą z całą potęgą, a wyszli z Krymu już 19 marca. I tylko wielkie śniegi uniemożliwiły im ruszenie tak szybkie i w takiej liczbie ${ }^{52}$. Widzimy więc, iż nuncjusz zawarł w tej relacji bardzo interesujące dane wojskowe, pozyskane z Mołdawii. Dwa tygodnie później donosił także, iż Turcy rozkazali obu hospodarom wspomóc Chmielnickiego, w czym nie mylił się, gdyż jego słowa potwierdza inny agent cesarski w Stambule, Szymon Reniger - notabene dobrze poinformowany, gdyż uzyskujący wiadomości m.in. wprost od agenta Rakoczego w Stambule, Zeldfikara agi ${ }^{53}$. Z relacji Renigera dowiadujemy się także, iż obaj

${ }^{47}$ G. de Torres do Rzymu, Warszawa, 26 XI 1650 r., Ватиканськи матеріали, nr 178, s. 97.

${ }^{48}$ G. de Torres do Rzymu, Warszawa, 17 XII 1650 r., Ватиканськи матеріали, nr 182, s. 99.

${ }^{49}$ G. de Torres do Rzymu, Warszawa, 26 XII 1650 r., Ватиканськи матеріали, nr 185, s. 100.

${ }^{50}$ Raporty G. de Torresa do Rzymu, Warszawa, 21 I i 4 II 1651 r., tamże, nr 191, s. 104-105 i nr 192, s. 105-106.

${ }^{51}$ R. Schmidt do Ferdynanda III, Stambuł, 10 III 1651 r., Жерела, nr 167, s. 164-165.

${ }^{52}$ G. de Torres do Rzymu, Warszawa, 15 IV 1651 r., Ватиканськи матеріали, nr 205, s. $113-114$

${ }^{53}$ G. de Torres do Rzymu, Warszawa, 29 IV 1651 r., Ватиканськи матеріали, nr 207, s. 114115, S. Reniger do Ferdynanda III, Stambuł, 22 V 1651 r., Жерела, nr 170, s. 166-167. Swoje kon- 
hospodarowie oświadczyli zgodnie, że w tak niepewnym czasie nie mogą zostawić swych państw bez obrony i zadeklarowali posłanie tylko po 8 tys. żołnierzy. Przypomnijmy na marginesie, że zdolności mobilizacyjne obu księstw naddunajskich oblicza się na połowę XVII w. na 8-10 tys. ludzi dla Mołdawii i 20 tys. dla Wołoszczyzny, tak więc wysłanie nawet owych 8 tys. przez Bazylego Lupula na Ukrainę rzeczywiście oznaczałoby ogołocenie kraju z wojska ${ }^{54}$.

Wiadomości z Mołdawii pojawiają się w korespondencji nuncjusza tuż przed rozstrzygającą bitwą pod Beresteczkiem. Oto w raporcie z 17 czerwca pisze on, iż syn Mikołaja Potockiego - najpewniej Piotr - wyszedłszy z Kamieńca Podolskiego rozbił 300-osobowy oddział jazdy, ochraniający posłów Chmielnickiego, wracających z listem hospodara. Uwięziwszy posłów, Potocki dowiedział się z listu, iż Lupul powiadamiał hetmana kozackiego o niemożliwości uzyskania pomocy ze Stambułu, co osładzał mu życzeniami podtrzymania przyjaźni i zawarcia małżeństwa córki z Tymofiejem ${ }^{55}$. Jak widzimy, chytry hospodar do końca łudził i zwodził Chmielnickiego, bo że przyjaźni ani spowinowacenia z nim wcale sobie nie życzył, to pokazała niedaleka już przyszłość.

Oto bowiem już pod koniec października 1651 r., zaledwie miesiąc po zawarciu ugody białocerkiewskiej, Giovanni de Torres, pisząc o przybyciu do Chmielnickiego rzekomo aż 40 tys. Tatarów na pomoc, dodawał, iż hetman kozacki chce użyć ich przeciwko Lupulowi, aby zmusić go wreszcie do oddania obiecanej już córki Tymofiejowi. Ponieważ jednocześnie Janusz Radziwiłł zapowiedział obronę teścia, nuncjusz - jak się okazało, proroczo - wyraził obawę, żeby, jeśli nie znajdzie się środków zaradczych, nie doszło z powodu tego małżeństwa do zerwania pokoju między Polakami a Kozakami ${ }^{56}$. Tydzień później, 4 listopada, pisał już, iż wobec tego, że zwrócenie się Chmielnickiego z ostatnimi posiłkami tatarskimi przeciw hospodarowi jest niemal pewne, król nakazał hetmanom koronnym wspomagać Lupula. Nuncjusz wyraża przy tym żywione w Warszawie nadzieje, iż Chmielnicki, znalazłszy na drodze do Mołdawii wojsko koronne, nie ośmieli się zaatakować i nadużyć okazanego mu niedawno miłosierdzia ${ }^{57}$. Jak wiemy, do konfrontacji wówczas rzeczywiście nie doszło, ostatnia zaś wzmianka o Mołda-

takty z Zeldfikarem agą wspomina S. Reniger w innym raporcie dla cesarza - zob. S. Reniger do Ferdynanda III, Stambuł, 22 IV 1651 r., Жерела, nr 168, s. 165.

${ }^{54}$ Z. Spieralski, Awantury, s 109-111, O. Górka, Dymitr Kantemir o wojsku i sztuce wojennej Mołdawian, „Studia i Materiały do Historii Sztuki Wojennej”, 3 (1956) s. 272.

${ }_{55}$ G. de Torres do Rzymu, Warszawa, 17 VI 1651 r., Ватиканськи матеріали, nr 218, s. 121-122.

${ }^{56}$ G. de Torres do Rzymu, Warszawa, 28 X 1651 r., Ватиканськи матеріали, nr 237, s. 137. Chan wysłał posiłki Kozakom jeszcze w czasie trwania kampanii 1651 r. - Islam Gerej III do B. Chmielnickiego, Krym, wrzesień 1651 r., w: J. Michałowski, Ksiega pamiętnicza, nr 239, s. 644. Z kolei hetman kozacki już w czasie bankietu, wydanego 28 września 1651 r. na cześć zawarcia ugody białocerkiewskiej odgrażał się, że zmusi hospodara do wydania córki za Tymofieja zob. Diariusz obozowy (rozpoczynajacy kampanię białocerkiewska 1651 roku), w: Relacje wojenne z pierwszych lat walk polsko-kozackich powstania Bohdana Chmielnickiego okresu „Ogniem i Mieczem" (1648-1651), oprac. M. Nagielski, Warszawa 1999, s. 305-306.

${ }^{57}$ G. de Torres do Rzymu, Warszawa, 4 XI 1651 r., Ватиканськи матеріали, nr 238, s. 137. Hetman M. Potocki skoncentrował wtedy wojska, aby przeciwstawić się ewentualnemu pochodo- 
wii $\mathrm{w}$ korespondencji nuncjusza $\mathrm{w}$ tym roku pochodzi z końca grudnia, kiedy to przekazywał on Kurii treść listu hospodara do króla, opisującą nietrwałość pokoju, kałmucki najazd na Krym i chańskie żądania udzielenia pomocy Tatarom przez Kozaków ${ }^{58}$. Jest to zatem świadectwo kontynuowania przez Lupula obyczaju informowania Rzeczypospolitej o wydarzeniach w państwie tureckim.

Rok 1652 przyniósł wreszcie realizację planów matrymonialnych Chmielnickiego, a zarazem wznowienie $\mathrm{z}$ tego powodu wojny na Ukrainie. Nuncjusz papieski zwrócił swe oczy ku Mołdawii dopiero w początkach maja, pisząc o wyruszeniu przeciwko obu hospodarom paszy tureckiego - najpewniej sylistryjskie$\mathrm{go}^{59}$. Jak się potem okazało, była to wiadomość przedwczesna, gdyż 1 czerwca nuncjusz pisał, ze pasza sylistryjski zbroi się dopiero z rozkazu sułtana, a i to nie wiadomo, czy przeciw Polsce i Kozakom, czy raczej przeciw Lupulowi ${ }^{60}$. Hospodar musiał czuć się zagrożony, przede wszystkim ze strony Kozaków, jednakże nawet pomimo dojścia do Warszawy w końcu maja 1652 r. wiadomości o wrogich poczynaniach Zaporożców, które przysłał hetman polny koronny Marcin Kalinowski, król nie chciał uwierzyć w niebezpieczeństwo, grożące Lupulowi. Jak dowiadujemy się od nuncjusza, Jan Kazimierz zwierzył mu się, iż nie dowierza alarmistycznym wiadomościom od hospodara, które sieją niepokój pomiędzy Polską a wrogami Lupula ${ }^{61}$. I nie ma w tym nic dziwnego, iż w Warszawie, zwłaszcza po zerwanym świeżo sejmie, który nie zatwierdził ugody białocerkiewskiej, chciano wierzyć raczej w utrzymanie pokoju z Kozakami, niż przyjąć do wiadomości groźne ostrzeżenia.

A tymczasem właśnie w początkach czerwca idąca ku Mołdawii armia kozacko-tatarska zniszczyła w bitwie pod Batohem zastępujące jej drogę wojska koronne. W pozbawionym obrony kraju wybuchła panika, której ślady znajdujemy w liście de Torresa z 16 czerwca 1652 r. Pisał on tam, iż nie wiadomo, czy po Batohu Tatarzy powrócą z łupem do siebie, czy ruszą w głąb Rzeczypospolitej, czy też wespół z Kozakami pójdą do Mołdawii, żeby obalić Lupula. Nuncjusz wierzy, iż hospodar z pewnością stawi wszelki możliwy opór, ponieważ już wcześniej mógł przewidzieć tę burzę i zebrał rzekomo aż 30 tys. żołnierzy ${ }^{62}$. Tymczasem Mołdawia nadal spełniała rolę informatora - do nuncjusza dotarły wiadomości z listu sekretarza hospodara, Jerzego Kutnarskiego, na temat ostatnich wydarzeń - niestety,

wi Kozaków i Tatarów na Mołdawię. S. Oświęcim, Stanisława Oświęcima dyariusz 1643-1651, w: Scriptores Rerum Polonicarum, t. 19, wyd. W. Czermak, Kraków 1907, s. 377.

${ }^{58}$ G. de Torres do Rzymu, Warszawa, 30 XII 1651 r., Ватиканськи матеріали, nr 240, s. 138.

${ }^{59}$ G. de Torres do Rzymu, Warszawa, 4 V 1652 r., Ватиканськи матеріали, nr 246, s. 140-141.

${ }^{60}$ G. de Torres do Rzymu, Warszawa, 1 VI 1652 r., Ватиканськи матеріали, nr 250, s. 142-143.

${ }^{61}$ G. de Torres do Rzymu, Warszawa, 25 V 1652 r., Ватиканськи матеріали, nr 249, s. 142.

${ }^{62}$ G. de Torres do Rzymu, Warszawa, 16 VI 1652 r., Ватиканськи матеріали, nr 253, s. 144 146. Dodajmy, ze poseł cesarski w Warszawie, zastepca Franciszka von Lisoli, Giovanni Morando Girardini, relacjonując $w$ tych dniach sytuację także pisał o 30 tys. żołnierzy Lupulowych, z którymi hospodar czekał na Tymofieja: „Qua reportata victoria [pod Batohem - D.M.] Chmielnickij filius partem Tartarorum cum captivis praedam iussit in Tartariam deducere, qui cum suo exercitu Moldauiam versus petijsse certo tenetur, ubi cum 30.000 hominum vires eius sustenendas animo resolutissimo Principem praestolari aiunt" - G. M. Girardini do grafa Kurza, Warszawa, 17 VI 1652 roku, Жерела, nr 191, s. 176. 
pismo, kierowane do kanclerza wielkiego koronnego Andrzeja Leszczyńskiego było na tyle lakoniczne, że nie wyjaśniało losów hetmana M. Kalinowskiego ${ }^{63}$. Najprawdopodobniej sami Mołdawianie nie wiedzieli jeszcze o jego śmierci w bitwie. Na przełomie czerwca i lipca pojawia się za to w listach nuncjusza najpierw nadzieja, a później pewność, iż hospodar za cenę dużego okupu zdołał skłonić Tatarów do odwrotu i uchronił Mołdawię przed ich ponownym najazdem ${ }^{64}$.

Nie zdołał jednak hospodar wymigać się tym razem przed oddaniem córki Tymofiejowi. W listach nuncjusza znajdujemy odbicie pełnych dramatyzmu ostatnich prób, podejmowanych przez Lupula, aby uniknąć tego małżeństwa. Oto dnia 27 lipca de Torres pisze, iż przybył do Warszawy posłaniec od Lupula i jego rady $\mathrm{w}$ Jassach, pokonując tę drogę ledwo w osiem dni. Z jego ustnej relacji oraz listu hospodara do króla wynikało, że Lupul wytargował u Kozaków 5 tygodni zwłoki do ślubu, który miał się odbyć w niedzielę, dnia 20 bieżącego miesiąca (w lipcu 1652 r. 20 lipca przypadał w sobotę, albo więc chodzi o ten dzień, albo o niedzielę 21 lipca). Hospodar kazał odesłać kobiety i ludzi niezdatnych do boju w góry, a sam zamknął się w swej umocnionej rezydencji z 40 tys. żołnierzy „z różnych narodów" (di varie nationi) - liczba z pewnością przesadzona, być może celowo, by Polacy nie postawili krzyżyka na hospodarze - i ma zamiar przeciwstawić się najazdowi, jeśli Kozacy i Tatarzy spróbują go napaść. W związku z tym prosił Rzeczpospolitą o jak najszybsze przysłanie posiłków, zanim minie owe pięć tygo$\mathrm{dni}^{65}$. Jak wiemy, hospodar pomocy nie otrzymał. W Warszawie akurat rozpoczą obrady sejm i kraj szykował się do obrony i rozprawy z Zaporożcami, ale póki co Polska nie była gotowa do działań. Lupul, będąc zdany na własne siły i ulegając naciskom oddolnym - mamy wiadomości, iż bliżej nie określony „lud”, a być może grupa bojarów, naciskali na hospodara, by dał córkę za Tymofieja i uchronił kraj od wojny ${ }^{66}$ - zmuszony był przyjąć propozycje kozackie. Swoją rolę grała też obawa przed zemstą Tatarów za pomoc w zorganizowaniu ucieczki polskich jeńców z Krymu - w tym przypadku Bazyli Lupul mógł liczyć jedynie na ochronę Mołdawii przez Kozaków, za cenę zgody na małżeństwo córki ${ }^{67}$. I to jednak - jak informuje nas Giovanni de Torres w swoim liście z 10 sierpnia - wysłał hospodar do Warszawy kolejne poselstwo, posługując się, dla utrzymania sekretu, jezuitą o. Stanisławem Szczytnickim. Zadeklarował przez niego, iż nadal sprzeciwia się małżeństwu córki z Tymofiejem, a ponieważ musi oddać córkę, tedy postara się

${ }^{63}$ G. de Torres do Rzymu, Warszawa, 22 VI 1652 r., Ватиканськи матеріали, nr 255, s. 146.

${ }^{64}$ G. de Torres do Rzymu, Warszawa, 29 VI 1652 r., Ватиканськи матеріали, nr 256, s. 146-147

i G. de Torres do Rzymu, Warszawa, 6 VII 1652 r., Ватиканськи матеріали, nr 257, s. 147-148.

${ }^{65}$ G. de Torres do Rzymu, Warszawa, 27 VII 1652 r., Ватиканськи матеріали, nr 2260, s. $149-150$.

${ }^{66}$ Wiadomość o tych naciskach na hospodara przekazuje G.M. Girardini: „Instat populus Moldauiensis apud suum Principem sibi procurandae pacis cum Cosacis et Tartaris, ut filiam suam filio Chmelnisky in matrimonium tradat, promissis suis et petitioni dicti Chmelnickii satisfaciat" - G. M. Girardini do grafa Kurza, Warszawa, 27 VII 1652 r., Жерела, 197, s. 178-179.

${ }^{67}$ Relacja F. Chiłkowa i P. Protasjewa dla Posolskiego prikazu, 15/25 VII 1652 r., w: Bocсоединение Украины с Россией, red. П. П. Гудзенко, t. 3, Москва 1954, nr 119, s. 226 (dalej: Воссоединение). 
to małżeństwo unieważnić jako wymuszone. Informował, że ślub planowany jest na granicy, w Jampolu - jak wiemy, ostatecznie odbył się w Jassach. Obiecał też wszelką pomoc pieniężną i wojskową Polsce, gdy ta, ujarzmiwszy Kozaków zechce wziąć odwet na Tatarach - przeciwko samym Zaporożcom jednak ingerować nie chce ${ }^{68}$. Ta powściągliwość wobec występowania przeciw Kozakom była niewątpliwie skutkiem obawy o los córki i miała decydujące znaczenie dla późniejszych dziejów hospodara. Bez wątpienia, Bohdanowi Chmielnickiemu powiodła się jedna rzecz - dostając w swe ręce Domnę Rozandę, otrzymywał zarazem gwarancję, że Lupul przeciw niemu nie wystąpi i choćby po niewoli, będzie musiał trwać przy Chmielnickim, jak wcześniej, gdy Rozanda znajdowała się jako zakładniczka w Stambule, trwał przy sułtanie. To zaś przekreśli go w oczach Polaków.

Nie trzeba było zresztą na to długo czekać, zwłaszcza jeśli chodzi o króla, który nigdy nie darzył hospodara szczególnym sentymentem. Na pewno „obciążało” Lupula w oczach króla małżeństwo córki hospodara z Januszem Radziwiłłem, do którego doszedł teraz nowy, niefortunny związek, jak i pamięć o zaangażowaniu się hospodara w czasie elekcji po stronie kandydata siedmiogrodzkiego ${ }^{69}$. Świadectwa takiej postawy króla znajdujemy w najbliższych relacjach nuncjusza - zresztą nowego już, gdyż Giovanni de Torres zakończył we wrześniu 1652 r. swoją misję. Zastąpił go biskup Lodi, Pietro Vidoni. Już jego pierwsza relacja o Mołdawii dotyczy zawartego w dniu 1 września 1652 r. małżeństwa Domny Rozandy z Tymofiejem Chmielnickim. Nuncjusz przekazał do Rzymu krótką informację o tym fakcie $\mathrm{w}$ dniu 21 września $^{70}$. Dużo ciekawsza jest wiadomość z 3 grudnia, w której nuncjusz, relacjonując rozmowę z Janem Kazimierzem, przekazuje obawy króla, aby hospodar, właśnie wskutek zawartego niedawno małżeństwa, nie okazał się wrogiem ${ }^{71}$. Co prawda postępowanie samego Lupula

${ }^{68}$ G. de Torres do Rzymu, Warszawa, 10 VIII 1652 r., Ватиканськи матеріали, nr 263, s. 151.

${ }^{69} \mathrm{O}$ podejrzeniach króla wobec hospodara w związku z elekcją 1648 r. i zarazem dążeniach Lupula do poprawy stosunków z Janem Kazimierzem zob. E. Baidaus, Politica şi diplomaţia Moldovei în timpul domniei lui Vasile Lupu (relaţii politice cu Republica Nobiliară Polonă şi Rusia Moscovită în anii 1634-1653), Chişinău 1998, s. 74, N. Iorga, Histoire des Roumains et de la romanité orientale, t. 6, Bucureşti 1940, s. 211 i D. Milewski, Mołdawia a Rzeczpospolita, s. 14-15.

${ }^{70}$ P. Vidoni do Rzymu, Warszawa, 21 IX 1652 r., Ватиканськи матеріали, nr 270, s. 157 -158. Opis wesela Rozandy Lupulówny i Tymofieja Chmielnickiego zob. Opisanie wesela Tymoszka syna Chmielnickiego z Rozanda córka Wasila Lupula hospodara woloskiego 1652, w: Л. Гвоздик, Анонімний „Опис весілля Тимоша Хмельницького” (1652) як історичне джерело, w: Наукові записки. Збірник пращь молодих вчених та аспірантів, t. 1, Київ 1996, s. 63-71.

${ }^{71}$ P. Vidoni do Rzymu, Łowicz, 3 XII 1652 r., Ватиканськи матеріали, nr 277, s. 162. Współczesny wypadkom historyk Wawrzyniec Rudawski pisał wprost, iż król był „zagniewany na hospodara wołoskiego [mołdawskiego - Mołdawię zwano wtedy Wołoszczyzną, a Wołoszczyznę Multanami - D.M.] z powodu zamążpójścia córki jego za syna Chmielnickiego" - W. Rudawski, Historia polska od śmierci Władysława IV aż do pokoju oliwskiego, wyd. W. Spasowicz, Sankt-Petersburg 1855, s. 226. Zupełnie inne stanowisko zajmował wojewoda kijowski, który spodziewał się okiełznania Chmielnickiego przez życzliwego Polsce hospodara. A. Kisiel do S. M. Jaskólskiego, Suchodoły, 30 X 1652 r., B.Czart., TN, nr 146, s. 247-248. Zob. też T. Ciesielski, Sejm brzeski 1653 r. Studium z dziejów Rzeczypospolitej w latach 1652-1653, Torun 2003, s. 30. 
zdawało się zaprzeczać tym podejrzeniom. Jesienią $1652 \mathrm{r}$. zaangażował się on w akcję mediacyjną między Rzecząpospolitą a Kozaczyzną, upatrując w pacyfikacji konfliktu własnych korzyści - miał wszak zobowiązania zarówno wobec Polski, jak i Kozaków. Inspirował też Janusza Radziwiłła do podjęcia się pośrednictwa w doprowadzeniu do pokoju na Ukrainie, jednakże akcja ta spełzła na niczym. Działania te, wobec polskich decyzji rozprawienia się z Kozakami siłą, mogły być jednak uznane za postępowanie wrogie Polsce ${ }^{72}$. Oto w dniu 26 lutego 1653 r. nuncjusz donosił, iż przybył do króla do Grodna od hospodara jezuita - najpewniej tenże Stanisław Szczytnicki - i opowiedział o stanie wiary katolickiej w Mołdawii i sentymentach samego Bazylego Lupula do katolicyzmu. Było to zapewne obliczone na uzyskanie poparcia nuncjusza oraz zneutralizowanie złego wrażenia, jakie łączyło się z faktem popierania sprawy hospodara przez jego zięcia, kalwinistę hetmana Janusza Radziwiłła. Przypomnijmy na marginesie, iż podczas odbytej w dniach 29-31 stycznia $1653 \mathrm{r}$. przedsejmowej rady senatu w Grodnie, nakłaniał on króla do przyjęcia oferty hospodara, który chciał pośredniczyć w doprowadzeniu do pokoju między Rzecząpospolitą a Kozakami, co szło zupełnie wbrew zamierzeniom króla, planującego podjęcie decydującej ofensywy przeciw Chmielnickiemu ${ }^{73}$. Tutaj - wedle słów nuncjusza - wysłannik Lupula zalecał coś wręcz przeciwnego, niż radził hetman litewski. Oto bowiem, wygłosiwszy ową kwestię o stosunkach religijnych w hospodarstwie, wysłannik Lupula ujawnił istotny cel swego przybycia, jakim było ni mniej ni więcej, tylko nakłonienie króla do jak najszybszego ruszenia przeciw Kozakom, zanim ci połączą się z Tatarami. Zalecał też uwadze króla swoją córkę na wypadek tej wojny, ponieważ po spodziewanej klęsce Kozaków łatwo mogła wpaść w polskie ręce. Król podszedł jednak nieufnie do tych rad, mimo iż szły one po jego myśli, gdyż - jak wyraził się wobec nuncjusza - nauczył się, iż hospodar podąża zawsze tam, gdzie widzi większą korzyść dla siebie ${ }^{74}$.

Ostatnią wiadomość z Mołdawii sprzed dokonanego tam przewrotu pałacowego i obalenia Bazylego Lupula, przekazał nuncjusz w relacji z czasu obrad sejmu brzeskiego, pisząc w dniu 9 kwietnia o listach z Mołdawii z wiadomościami o ruszeniu się 12 marca chana na pomoc Kozakom ${ }^{75}$. Listy te przywiózł zapewne sekretarz Lupula, Jerzy Kutnarski, który przybył na sejm, by ofiarować

${ }^{72}$ Stanowisko króla wobec prób pojednania z Kozakami wyraził najdobitniej sam monarcha zob. Jan Kazimierz do B. Chmielnickiego, Brześć Litewski, 15 III 1653 r., BUWr, Akc. 1949/440, k. 554v. Na temat akcji mediacyjnej hospodara i współdziałania w niej Janusza Radziwiłła zob. J. Kutnarski do A. Leszczyńskiego, Jassy, 19 XII 1652 r. i S. Potocki do Jana Kazimierza, Podhajce, 26 XII 1652 r., tamże, k. 544-544v i 545, S. Szczytnicki do A. Leszczyńskiego, Jassy, 18 X 1652 r., B. Czart., TN, nr 146, s. 242, a także Memoriał J. Radziwiłła w relacji posłów B. Chmielnickiego do cara, K. Burłaja i S. Mużyłowskiego. Zob. Relacja K. Burłaja i S. Mużyłowskiego w Posolskim prikazie, 22 IV/2 V1653 r., Воссоединение, t. 3, nr 153, s. 264-266.

${ }^{73}$ Szerzej na ten temat zob. М. Грушевський, Історія України-Руси, t. 9, Київ 1996, s. 489-490, M. Matwijów, Próba mediacji hetmana litewskiego Janusza Radziwiłła w konflikcie polsko-kozackim w latach 1653-1655, „Wrocławskie Studia Wschodnie”, 2001, t. 5, s. 11-12 T. Ciesielski, Sejm brzeski, s. 74-77.

${ }^{74}$ P. Vidoni do Rzymu, Grodno, 26 II 1653 r., Ватиканськи матеріали, nr 282, s. 165-166.

${ }^{75}$ P. Vidoni do Rzymu, Brześć Litewski, 9 IV 1653 r., Ватиканськи матеріали, nr 286, s. 168. 
pośrednictwo hospodara w konflikcie polsko-kozackim ${ }^{76}$. Ludwik Kubala datuje jego przybycie na 5 kwietnia, a wiemy z pamiętników kanclerza wielkiego litewskiego Albrychta Stanisława Radziwiłła, iż dyskutował on z Januszem Radziwiłłem, kanclerzem koronnym Stefanem Korycińskim i podskarbim koronnym Bogusławem Leszczyńskim nad propozycjami, zawartymi w listach Lupula, w dniu 5 lub 8 kwietnia (Radziwiłł dwukrotnie podaje informację o tym, pod tymi dwiema datami) ${ }^{77}$. W każdym bądź razie, 9 kwietnia nuncjusz mógł już pisać o tych listach, bo sprawa była przedyskutowana. Następne wiadomości dotyczyć już będą okoliczności zrzucenia Lupula z tronu w dniach 10-13 kwietnia $1653 \mathrm{r}$. oraz rozpętanej w ich następstwie wojny o panowanie nad Mołdawią.

Już 25 kwietnia relacjonował nuncjusz Vidoni te wydarzenia, pisząc o ,zadziwiającej wieści" (avviso assai considerabile), iż Jerzy Rakoczy i Mateusz Basarab zajęli Mołdawię i uczynili tamtejszego logofeta hospodarem. Dalej relacjonuje nuncjusz, iż Lupul z większą częścią skarbu uciekł do pogranicznej twierdzy, a żonę i dzieci odesłał do Kamieńca Podolskiego. Vidoni uważał, że Chmielnicki będzie musiał okazać pomoc teściowi swego syna i znalazł okazję do zajęcia Mołdawii przez Tymofieja. Nie wiadomo było jeszcze, czy zaszłe wypadki były za wiedzą Porty. Król zwołał naradę i ofiarował Lupulowi możliwość przyjazdu do Lwowa oraz zdecydował wysłać jezuitę, by na miejscu przyjrzał się sprawie i sprawdził, czy hetman kozacki postanowił interweniować w Mołdawii czy też kontynuować wojnę przeciw Polsce ${ }^{78}$.

$\mathrm{Z}$ dnia 1 maja 1653 r. mamy dwie relacje Pietra Vidoniego, dotyczące spraw mołdawskich. W pierwszej donosi on o przyjściu listu od Rakoczego, w którym ten uzasadniał swój najazd na Mołdawię i zapewniał, że nie obróci się on przeciw Polsce (nuncjusz ma tu na myśli list Rakoczego do króla, wysłany z Feldvaru 25 marca). Sam Lupul schronił się ze skarbem i garstką ludzi w Kamieńcu. Vidoni kończy informacją, iż król niebawem wyjedzie do Janowa, skąd udzieli odpowiedzi Lupulowi ${ }^{79}$. W drugiej relacji czytamy, iż przyszły listy z Podola, z których nuncjusz dowiedział się, iż machinacje Rakoczego i Basaraba przeciw Lupulowi z udziałem logofeta Jerzego Stefana zaczęły się już po ślubie Tymofieja, z którego logofet był niezadowolony. Znając wszystkie sekrety Lupula, mógł łatwo zainteresować Rakoczego i Basaraba pochwyceniem hospodara. Nuncjusz dodaje, iż w ostatnią niedzielę, tj. 27 kwietnia, przybył szlachcic wysłany przez Rakoczego w celu przedstawienia, iż Lupul żywił wrogie zamiary wobec wszystkich sąsiadów

${ }^{76}$ Bazyli Lupul do Jana Kazimierza, Jassy, 25 III 1653 r., w: Documente privitoare, nr 97, s. 164-165: „Nieustawając ja tedy w tym, co humeris meis od WKMci PM Miłościwego jest impositum, jaką i natenczas od Chmielnickiego in scriptis otrzymałem deklaracją przez urodzonego Jerzego Kutnarskiego sekretarza mego nulla interiecta mora WKM Panu Memu Miłościwemu one przesyłam".

${ }^{77}$ A.S. Radziwiłł, Pamiętnik o dziejach w Polsce, wyd. A. Przyboś, R. Żelewski, t. 3, Warszawa 1980, s. 385-386, L. Kubala, Wyprawa żwaniecka, w: Szkice historyczne. Seria 2, Lwów 1880, s. 192.

${ }^{78}$ P. Vidoni do Rzymu, Brześć Litewski, 25 IV 1653 r., Ватиканськи матеріали, nr 288, s. $169-170$.

${ }^{79}$ P. Vidoni do Rzymu, Brześć Litewski, 1 V 1653 r., tamże, nr 289, s. 170-171. Wspomniany list Rakoczego zob. Jerzy Rakoczy do Jana Kazimierza, Feldvar, 25 III 1653 r., Жерела, nr 227, s. 193. 
i przedstawił racje, dla których go obalono. Wiadomo też było nuncjuszowi, iż Lupul jest jeszcze w Kamieńcu z zaledwie 15. osobami i że na ostatniej radzie nie podjęto wobec niego ostatecznej decyzji. Wysłano natomiast $\mathrm{w}$ ostatnim tygodniu osobę w tamte kraje (nuncjusz ma na myśli zapewne wspomnianego w liście z 25 kwietnia jezuitę, prawdopodobnie o. Stanisława Szczytnickiego) ${ }^{80}$.

W Mołdawii tymczasem rozpoczęła się wojna, gdyż Tymofiej Chmielnicki interweniował w obronie teścia. Donosi o tym nuncjusz w liście z 19 maja, pisząc, iż Kozacy z 15 tys. Tatarów weszli do Mołdawii i w krwawej bitwie niedaleko Jass pobili logofeta, mimo iż miał on 25 tys. jazdy węgierskiej. Zmuszony do ucieczki, zostawił kraj na łasce Kozaków. Sam Chmielnicki zaś prosił króla o pomoc przeciwko wspólnym nieprzyjaciołom, Siedmiogrodzianom i Wołochom ${ }^{81}$. Tydzień później pisał już nuncjusz o stosunku Turków wobec wydarzeń w Mołdawii oraz o oczekiwaniu logofeta, Basaraba i Rakoczego na połączenie ich sił i pomoc turecką. Donosił także o śmierci J. Kutnarskiego z ręki Tymofieja oraz o zganieniu w Polsce łatwości, z jaką Lupul wraz ze skarbem opuścił Kamieniec ${ }^{82}$. Tegoż dnia nuncjusz wysłał kolejny, obszerniejszy raport na temat sytuacji w Mołdawii. Pisał w nim, iż wskutek sukcesów Tymofieja Lupul powrócił do władzy w Mołdawii, a logofet zbiegł z kraju. Tymofiej z 10 tys. Kozaków i 3 tys. Tatarów - liczba przesadzona, jak wiemy - nadszedł szybko ku Jassom i zajął je bez trudu, pokonawszy logofeta, po czym natychmiast wezwał Lupula. Jerzemu Kutnarskiemu, który był na sejmie w Brześciu, Tymofiej osobiście ściął głowę pod pretekstem, iż Kutnarski informował Polaków o posunięciach Kozaków. Lupul dokłada wszelkich starań, by powstrzymać Kozaków od wszczęcia wojny z Polską. Chmielnicki niecierpliwie oczekuje nadejścia wielkiej ordy, król zaś przed wyjściem w pole chce się naradzić, co przedsięwziąć na wypadek, gdyby miało dojść do sojuszu z sąsiadami - jak wiemy, zarówno Jerzy Stefan, jak i sam Rakoczy wystąpili wobec króla z taką ofertą - i w tym celu król wezwał na naradę kilku głównych senatorów, którzy znajdowali się akurat na dworze ${ }^{83}$.

${ }^{80}$ P. Vidoni do Rzymu, Brześć Litewski, 1 V 1653 r., Ватиканськи матеріали, nr 290, s. $171-172$.

${ }^{81}$ P. Vidoni do Rzymu, Warszawa, 19 V 1653 r., tamże, nr 291, s. 172-173. Nuncjusz ma na myśli zwycięstwo Tymofieja w bitwie pod Popricani, stoczonej 1 V 1653 r., o której informował króla sekretarz Lupula - zob. J. Kutnarski do Jana Kazimierza, obóz pod Chocimiem, 6 V 1653 r., w: Documente privitoare, nr 109, s. 178-179. Dodajmy, iż informacje nuncjusza o siłach tatarskich są zgoła fantastyczne, gdyż tenże J. Kutnarski, będąc bliżej wydarzeń, oceniał siły Tymofieja na 12 tys. Kozaków i zaledwie 200 Tatarów. On sam jednak obliczał siły nowego hospodara na ponad 20 tys., podczas gdy bliższy prawdy jest chyba kronikarz mołdawski Miron Costin, podający siły Jerzego Stefana na 12 tys. ludzi - zob. M. Costin, Latopis ziemi mołdawskiej i inne utwory historyczne, wyd. I. Czamańsk,. Poznań 1998, s. 204.

${ }^{82}$ P. Vidoni do Rzymu, Warszawa, 26 V 1653 r., Ватиканськи матеріали, nr 292, s. 173-174.

${ }^{83}$ P. Vidoni do Rzymu, Warszawa, 26 V 1653 r., Ватиканськи матеріали, nr 293, s. 174-176. Inaczej śmierć J. Kutnarskiego przedstawia M. Costin, według którego Tymofiej zaprosił go na naradę do monasteru Galata, po czym zasadził nań pod drzwiami kilku Kozaków z szablami, którzy rozsiekali sekretarza Lupula, gdy ten wychodził po rozmowie z Tymofiejem - zob. Costin, Latopis, s. 206. 
Następne relacje nuncjusza dotyczą wyprawy Tymofieja na Wołoszczyznę, zakończonej - jak wiemy - klęską Kozaków w bitwie nad Jałomicą 27 maja 1653 r. W dniu 1 czerwca Vidoni informował Kurię, iż Tymofiej z 20 tys. ludzi pomaszerował przeciw Węgrom i Wołochom, i oczekuje się, że do tej pory doszło już do bitwy. Natomiast żona Lupula z częścią skarbu nadal przebywała w Kamieńcu, a sam hospodar w Jassach pod opieką 3 tys. Kozaków, zostawionych mu przez Tymofieja ${ }^{84}$. Tydzień później przekazywał już nuncjusz wiadomość o klęsce Tymofieja, która przyszła do Warszawy z Podola 4 czerwca ${ }^{85}$. Wreszcie 14 czerwca Pietro Vidoni potwierdza poprzednią wiadomość, na podstawie relacji nadesłanej z Kamieńca Podolskiego przez Piotra Potockiego. Dodawał też opis okrucieństwa Tymofieja, który kazał Kozakom strzec teścia, zabił jego sekretarza i wielu innym osobom groził śmiercią. Po zabiciu Kutnarskiego zaś miał rzec: „Byłem pijany, a wy, którzy mi zawadzacie, nie unikniecie kary" ${ }^{\prime 6}$.

W kolejnej relacji, z 22 czerwca, nuncjusz opisywał ucieczkę pobitego Tymofieja wraz z Lupulem do tureckiej Braiły (tym samym potwierdzając udział hospodara w wyprawie). Cała armia została rozproszona, oprócz dwóch oddziałów, które pod wodzą Iwana Bohuna wycofały się do Jass. Były pogłoski o wsparciu tureckim dla wojsk wołosko-węgierskich, ale sam nuncjusz uważał je za wątpliwe. Chmielnicki czekał w Czehryniu na ordę, a tymczasem operujący na Podolu dowódca polski Jan Kondracki wziął szturmem Jaruszów, zabijając tam 200 Kozaków, zagarnął w innej miejscowości 2 tys. sztuk bydła, które odprowadził do Kamieńca i znów ruszył w pole, by przechwytywać Kozaków, uciekających z Mołdawii na Ukrainę ${ }^{87}$.

W kolejnym liście nuncjusz porusza sprawę zatrzymania bądź wypuszczenia z Kamieńca żony Lupula wraz ze skarbami oraz przypuszczenia, że Porta ma chęć dokonać inwazji na Mołdawię. Relacjonuje też przybycie posła z listem od Rakoczego do króla, w którym książę siedmiogrodzki prosił, by król nie wypuszczał żony Lupula z Kamieńca i sam deklarował okazać królowi wszelką pomoc. Przypominał nuncjusz o podobnym liście, wysłanym wcześniej do komendanta kamienieckiego z Jass (chodzi tu zapewne o list Jana Keménya do „ichmciów w Kamieńcu rezydujących" z 16 kwietnia 1653 r., w którym zawiadamiał o obaleniu Lupula i przyjaźni wobec Rzeczypospolitej) ${ }^{88}$.

${ }^{84}$ P. Vidoni do Rzymu, Warszawa, 1 VI 1653 r., tamże, nr 294, s. 176-177. W rzeczywistości Bazyli Lupul wziął udział w wyprawie - zob. M. Costin, Latopis, s. 207-212 i Relacja z wojny motdawsko-wołoskiej, 1653, Documente privitoare, nr 113, s. 183-184.

${ }^{85}$ P. Vidoni do Rzymu, Warszawa, 8 VI 1653 r., Ватиканськи матеріали, nr 295, s. 177.

${ }^{86}$ P. Vidoni do Rzymu, Warszawa, 14 VI 1653 r., tamże, nr 296, s. 177-178. Kronikarz mołdawski zostawia nam wiadomość, że Tymofiej groził także dwornikowi Tomie i wisternikowi Iordachemu, którzy też byli swego czasu przeciwni małżeństwu Tymofieja z Rozandą - M. Costin, Latopis, s. 206-207.

${ }^{87}$ P. Vidoni do Rzymu, Warszawa, 22 VI 1653 r., Ватиканськи матеріали, nr 297, s. 178-179. $\mathrm{Na}$ temat działań J. Kondrackiego wiosną 1653 r. zob. D. Milewski, Wyprawa na Suczawę 1653, Zabrze 2007, s. 72-73.

${ }^{88}$ P. Vidoni do Rzymu, Warszawa, 29 VI 1653 r., Ватиканськи матеріали, nr 298, s. 179-180, J. Kemény do panów w Kamieńcu, Jassy, 16 IV 1653 r., Documente privitoare, nr 100, s. 168-169. 
Są to ostatnie relacje nuncjusza, dotyczące Mołdawii - następne pojawią się dopiero jesienią 1653 r. W zbiorze S. Tomasziwskiego listy Pietra Vidoniego z okresu wojny 1653 r. są stosunkowo rzadkie, wiemy jednak, że nuncjusz miał dobre i szczegółowe informacje od sekretarza Paola Doniego, który odbywał kampanię żwaniecką przy boku królewskim ${ }^{89}$. W dniu 25 października 1653 r. przekazał nuncjusz do Rzymu wiadomości od sekretarza wielkiego koronnego Stefana Wydżgi (il signor abbate Visga gran secretario del regno), iż Rakoczy, logofet i Basarab odmówili połączenia swych wojsk z Polakami i wymarszu przeciw Kozakom, a z kolei 5 tys. Kozaków, których oblegano w Suczawie i którzy mieli służyć w wojsku królewskim, dostało pozwolenie odejścia. Powołując się na doniesienia P. Doniego, nuncjusz krytykował postawę sprzymierzeńców, dla których Polacy poświęcili najlepszy czas na prowadzenie wojny ${ }^{90}$. W kolejnym liście jednak pisze już o nadejściu posiłków od Rakoczego i hospodarów w sile 4 tys. żołnierzy, z zastrzeżeniem, by nie walczyli przeciw Tatarom, aby nie drażnić Turków $^{91}$. Wreszcie w ostatnim z listów, w których porusza sprawy mołdawskie, z 8 listopada 1653 r., pisze nuncjusz, powołując się znów na doniesienia P. Doniego, o wysłaniu do króla posłów od Rakoczego i hospodarów - nie wiedział jednak, z jakimi decyzjami jechali ${ }^{92}$.

Podsumowując nasze rozważania na temat tematyki mołdawskiej, zawartej w doniesieniach nuncjuszów apostolskich z lat 1648-1653, musimy odpowiedzieć na pytanie, co interesowało dyplomatów papieskich i w jakim stopniu ich informacje są wiarygodne. Zainteresowania nuncjuszów Mołdawią nie zawsze były równie intensywne, a wiązały się z coraz to nowymi problemami. Aż do końca 1648 r. Mołdawia pojawia się stosunkowo rzadko w raportach i to przeważnie tylko jako źródło wiadomości o Turcji. Z początkiem roku 1649 informacje stają się częstsze i wiążą się z obawą o związanie się Bazylego Lupula sojuszem z Bohdanem Chmielnickim. Kampania zborowska wykazała bezpodstawność tych obaw i zara-

${ }^{89}$ Jego relacje do nuncjusza od 23 VI do 15 XII 1653 r. wydał S. Tomasziwskij: Листи королівського секретаря Паоло Дони до римского нуния Пєетро Відоні з 1653 p., wyd. С. Томашівський, w: Юбилейный збирник на поману академика Дмитра Ивановича Багалия. Київ 1927, s. 529-579.

${ }^{90}$ P. Vidoni do Rzymu, Warszawa, 25 X 1653 r., Ватиканськи матеріали, nr 302, s. 181182. Ocena wyprawy suczawskiej przez współczesnych i potomnych zob. D. Milewski, Wyprawa, s. $145-159$.

${ }^{91}$ P. Vidoni do Rzymu, Warszawa, 1 XI 1653 r., Ватиканськи матеріали, nr 303, s. 182-183. Zob. Krótka narratywa ekspedycyi w roku 1653 po świątkach przeciwko rebelii kozackiej z potęgą tatarską po szósty raz stoczonej, B.Czart., TN, nr 147, s. 157: „Węgrowie z strony dawania kwoty posiłków długo się umawiali, raz składając się tym, że będąc feudales cesarza tureckiego, nie godziło się im przeciwko Tatarom, jako hołdownikom także cesarza tureckiego wojować".

${ }_{92}$, „E s aggiumge che l’ambasciatori del Transilvano e principi palatini fossero stati spediti da sua maestà, ma non si sapeva per anco con quali risolutioni" - P. Vidoni do Rzymu, Warszawa, 8 XI 1653 r., Ватиканськи матеріали, nr 304, s. 183. Posłowie - w imieniu księcia siedmiogrodzkiego wystąpił Jan Bethlen de Bun - zostali przyjęci przez króla w dniach 18-20 X 1653 r. O tym oraz o posiłkach siedmiogrodzkich i mołdawsko-wołoskich zob. T. Ciesielski, Od Batohu do Żwańca. Wojna na Ukrainie, Podolu i o Mołdawię 1652-1653, Zabrze 2007, s. 230-231 i Milewski, Wyprawa, s. 141-142. 
zem usunęła Mołdawię z pola widzenia nuncjusza. Powraca ona w końcu 1649 r. w kontekście odnowionych planów wojny tureckiej, jako spodziewany sojusznik Polski. W tym znaczeniu funkcjonuje ona w korespondencji nuncjusza jeszcze $\mathrm{w}$ pierwszej połowie $1650 \mathrm{r}$. Jesień tego roku, naznaczona tatarsko-kozackim najazdem na Mołdawię i przekreśleniem planów tureckich dworu, po raz pierwszy owocuje rzeczywistym dużym zainteresowaniem nuncjusza krajem Lupula. Od sprawy najazdu przejdzie ono do jego politycznych konsekwencji, czyli planów małżeńskich Chmielnickiego. Interesować one będą nuncjusza jesienią 1650 r. i słabiej nieco w pierwszej połowie roku następnego, by znów nasilić się jesienią $1651 \mathrm{r}$., gdy Chmielnicki usiłował zrealizować swoje zamiary i osiągnąć swe apogeum latem 1652 r., po klęsce batohowskiej. Zmiana na stanowisku nuncjusza we wrześniu 1652 r. nie wpłynęła na optykę postrzegania spraw mołdawskich. Po zawarciu małżeństwa Tymofieja z Rozandą Lupulówną nuncjusza interesuje wiarygodność hospodara jako sojusznika Polski. Z chwilą obalenia Bazylego Lupula i wybuchu wojny o Mołdawię między dwoma wrogami Polski - Siedmiogrodem i Kozakami - sprawy mołdawskie wysuwają się na pierwsze miejsce w relacjach nuncjusza, co jest prostym odzwierciedleniem wzmożonego zainteresowania tym krajem i toczącą się wojną, jakie okazywał król w przededniu wyprawy na Ukrainę.

Czy i w jakim zakresie relacje nuncjuszów są wiarygodnym źródłem historycznym? To zależy od tego, na ile nuncjusz był sam świadkiem opisywanych wydarzeń, a na ile miał dostęp do dobrych informacji. Widzimy, że często doniesienia z Mołdawii bywały dosyć bałamutne - jak choćby w kwestii liczebności wojsk czy szczegółów wydarzeń w wiosennych walkach 1653 r. albo co do istotnej postawy Lupula wobec Polski i Kozaków zimą i wiosną 1649 r. Kiedy jednak nuncjusz korzysta z doniesień sekretarza P. Doniego, jego wiadomości o wypadkach wojennych z jesieni 1653 r. są dokładne i prawdziwe. Niewątpliwie jednak doniesienia nuncjuszów pozostają pierwszorzędnym źródłem, jeśli chodzi o politykę dworu królewskiego wobec Mołdawii - czy to planów włączenia jej do ligi antytureckiej, czy obaw o sojusz z Kozakami zimą 1652/53 r. - oraz w kwestii osobistego stosunku króla do Bazylego Lupula. Stosunek ten miał okazję poznać nuncjusz w trakcie osobistych, poufnych rozmów z Janem Kazimierzem, a wiemy, iż to właśnie m.in. podejrzliwość króla wobec hospodara jako „Radziwiłłowskiego teścia" zdecydowała o przeforsowaniu przez monarchę, wbrew opozycji wielu senatorów, decyzji o zawarciu w 1653 r. przymierza z Siedmiogrodem i wysłania polskich wojsk do Mołdawii przeciw Kozakom Tymofieja.

Przyjmując wreszcie, iż nuncjusze, pisząc raporty do Kurii Rzymskiej nie mieli powodu, by zatajać bądź przeinaczać uzyskane wiadomości, możemy uznać, że - w podanym wyżej zakresie - ich doniesienia są dobrym źródłem do poznania historii stosunków polsko-mołdawskich w latach 1648-1653. 


\title{
LA MOLDAVIE DANS LES RELATIONS DES NONCES APOSTOLIQUES EN POLOGNE DE 1648 À 1653
}

\begin{abstract}
Résumé
La Moldavie, un allié potentiel de la Pologne contre les Turcs, intéressait les nonces apostoliques en Pologne. Quand l'insurrection des Cosaques en Ukraine a éclaté en 1648, la Moldavie est devenue importante pour les nonces comme la source des informations des événements en Porte Ottomane et de la politique des Cosaques et Tatars. Les nonces observaient le prince de la Moldavie, Basile Lupul, quand il louvoyait entre les Polonais et les Cosaques, ils s`intéressaient à l'invasion des Tatars et Cosaques en 1650 et au mariage de la fille du prince Basile et le fils de Bogdan Chmilnitzki, l'hetman cosaque. Après ce mariage en 1652, la Moldavie a été perdue pour la Pologne, mais la chute du prince Basile en 1653 et la guerre de la Transylvanie et Valachie contre les Cosaques ont créé une nouvelle possibilité de la reconstruction des influences polonaises dans ce pays. Les relations exactes des nonces, que nous avons, sont une bonne source pour une connaissance de tous ces événements et surtout le rapport personnel du roi Jean Casimir à la Moldavie et son prince, Basile Lupul.
\end{abstract}

